DOI: 10.20472/IAC.2018.043.054

PETER WUI

University of Arkansas Pine Bluff, United States

\section{LAWRENCE AWOPETU}

University of Arkansas Pine Bluff, United States

\title{
IMPACT OF WORKING CAPITAL (WC) STRATEGIES ON SMALL BUSINESS PROFITABILITY DURING RECESSION
}

\begin{abstract}
:
Small business is most numerous type of business in the United States with about 90 percent failure rate within the first 2 years of its establishment. This study investigated the impact of finance and investing strategies on small businesses before and after the great recession that started in late 2007. Data for this study was from the best profitable 100 small businesses as published by Forbes in 2011. The multivariate panel regression models were estimated using published financial statements of the surveyed 72 companies from year 2002 to 2011 . The study outcomes show that when WC strategies (finance and investing policies) are prudently and efficiently applied to business operations it will increase profitability. It further indicated that less working capital (aggressive financing strategy) would increase return on assets before and after economic recession. The aggressive strategy will positively reflect on Tobin's Q during normal time; but during recession, only less current liability capital will be effective. The study further revealed that return on equity (ROE) will be effective only when current liability is regressed on total assets during normal times, and no change is observed during economic recession.
\end{abstract}

\section{Keywords:}

Small Business, Working Capital Strategy, Recession

JEL Classification: G30, G32, G01 